\title{
Effect of Drought Stress on Yield and Yield Components of 20 Peanut Genotypes Grown under Newly Reclaimed Soil
}

\author{
S.M.A. Nassar\# , A.M.A. Al-Kady and Z.I. El-Saka \\ Plant Genetic Resources Department, Desert Research Center, El-Matarya, Cairo, \\ Egypt.
}

\begin{abstract}
$\mathbf{T}$ HIS INVESTIGATION was carried out to evaluate the performance of some yield characteristics for twenty peanut genotypes of different origins under two irrigation treatments. The experiment was conducted during the two successive seasons 2015 and 2016 at the Experimental Station of Desert Research Center, Toshka, Egypt. Losses in peanut line yield and yield component are maximized at drought treatment. The main objective of this investigation was to study the effects of deficit irrigation (I) in genotype (G) and $G \times I$ interaction on yield component and yield traits in peanut genotypes. A split plot design was used, where the irrigations were allotted to two irrigation treatments, i.e. well watering by giving all recommended irrigations $\left(3500 \mathrm{~m}^{3} / \mathrm{fad}\right)$ and water stress by giving $67 \%$ from recommended irrigations $\left(2345 \mathrm{~m}^{3} / \mathrm{fad}\right)$, while sub plots were allotted to genotypes. Water stress caused a significant decrease in pod yield/ha, pod yield/plant, seed weight/plant, no. of pod/plant, no. of seed/pod and 100 seed. The rank of genotypes for studied traits under water stress was changed from that under well watering conditions. The peanut lines L11 and L17 were the highest values for pod yield/plant and other studied traits, L11 for seed weight/plant and number of seeds/plant, and L3 for 100 seed weight.
\end{abstract}

Keywords: Groundnut, drought stress, Tolerance index, Genotype $\times$ irrigation interaction, Reclaimed soil.

\section{Introduction}

Water deficit stress is one of the major environmental constraints limiting agricultural productivity and plays a major role in the distribution of plant species across different types of environments (Ashraf, 2010). Two-thirds of the potential yields of major crops are usually lost due to adverse growing environments (Chaves et al., 2009). Drought or water deficit condition can be defined as the absence of adequate moisture necessary for normal plants to grow and complete their life cycle (Zhu, 2002).

Knowledge on the performance and adaptability of genotypes to particular environments is fundamental to estimate the agronomical value of cultivars and for their recommendation for specific environments (Murakami et al., 2004).

Peanut (Arachis hypogaea L.) is the world's $4^{\text {th }}$ most important edible oil crop and $3^{\text {rd }}$ most important source of vegetable protein (CGIAR, 2005). However, over $97.6 \%$ of world peanut area and about $95.5 \%$ of total production is concentrated in developing predominantly in Asia and Africa, where crop is grown mostly under rain-fed conditions (ICRISAT, 2011). In these regions, low rainfall and prolonged dry spells during crop growth period are main reason for low yields and constraint to peanut production (Kumar, 2007).

Peanut is an important legume crop grown in tropical and sub-tropical semi-arid regions of the world; the yield level is severely affected by shortage of soil moisture. Peanut (Arachis hypogaea L.) is an important seed legume in Egypt as compared with other oil crops. It is considered as the most popular oil seed in the world, following soy, cotton and canola (Arruda et al., 2015). This crop is adapted to tropical and semiarid regions

"Corresponding author email: saad3a@yahoo.com 
(Pereiral et al., 2015). Peanut is mainly used for human consumption and oil production as it has a valuable commercial oil $40-60 \%$, in addition to high protein content (16-28\%). The level of damage caused by water stress is determined by plant growth stage, intensity and duration of the stress. Water deficit during flowering and seed development has sever effect on the pod and seed yield as compared with other growth stages. Therefore, resistance to drought is a very desired trait in breeding programs (Perierel et al., 2015).

The overall objective of the present research was to select genotypes with high tolerance to intermittent drought. This effort included the following steps: (i) To determine the effects of drought stress on yield component and yield, (ii) To estimate the effects of peanut genotype and genotype $\times$ irrigation interaction on such traits, (iii) Classify studied genotypes based on efficiency vs responsiveness, yielding ability vs drought tolerance.

\section{Materials and Methods}

This study was carried out at Toshka Station, Desert Research Center, Aswan, Egypt, 2015 and 2016 seasons.

\section{Experimental design}

Four field evaluation experiments were carried out in 2015 and 2016 seasons at Toshka Station, Desert Research Center, Aswan, Egypt, and two drought stress levels. Drip irrigation system was applied in these experiments using drippers every day. The drought stress levels were the normal condition $\left(100 \%\right.$ of field capacity $\left(3500 \mathrm{~m}^{3} / \mathrm{fad}\right)$ and the drought stress $(67 \%$ of normal condition $\left(2345 \mathrm{~m}^{3} / \mathrm{fad}\right)$, Each experiment contained 20 genotypes (Table 1) designed in a randomized complete block design with three replicates. Each genotype was allotted in two rows plot of $10 \mathrm{~m}$ long and $60 \mathrm{~cm}$ apart with $30 \mathrm{~cm}$ between hills (one plant per hill). The preceding crops were wheat and faba been in the first and second seasons, respectively.

TABLE 1. The origin of the used genotypes.

\begin{tabular}{lccccc}
\hline No. & Entry & Origin & No. & Entry & Origin \\
\hline 1 & Line 25 & Israel & 11 & Line 13 & Zambia \\
2 & Line 35 & China & 12 & Line 3 & Brazil \\
3 & China 34 & 13 & Line 4 & Brazil \\
4 & Line 50 & Mexico & 14 & Line 41 & China \\
5 & Line $27 \mathrm{r}$ & Israel & 15 & Line 18 & Israel \\
6 & Line 28 & Israel & 16 & Line 43 & China \\
7 & Line 26 & Israel & 17 & Line 8 & Malawi \\
8 & Line 27 & Israel & 18 & Line 6 & Brazil \\
9 & Line 9 & Malawi & 19 & G 13 & Egypt \\
10 & Line 10 & Malawi & 20 & NC (Cheek) & USA \\
\hline
\end{tabular}

Agriculture practices

Planting was done in the two summer seasons at $14^{\text {th }}$ and $5^{\text {th }}$ of April in 2015 and 2016, respectively. All other cultural practices were done according to the slandered recommendations for sowing peanut in Toshka station.

Soil type of experimental site

The soil analysis of the experimental soil at the
Experimental Station of Desert Research Center, Toshka, Egypt, as an average of the two growing seasons 2015 and 2016 (Table 2).

The climatic of experiment in Toskha

The climatic differences over experimental years are shown in Table 3.

TABLE 2. Some physical and chemical properties of experimental sites.

\begin{tabular}{|c|c|c|c|c|c|c|c|c|c|c|c|c|c|c|c|}
\hline \multirow{2}{*}{$\begin{array}{c}\text { Sand } \\
(\%)\end{array}$} & \multirow{2}{*}{$\begin{array}{l}\text { Silt } \\
(\%)\end{array}$} & \multirow{2}{*}{$\begin{array}{l}\text { Clay } \\
(\%)\end{array}$} & \multirow{2}{*}{ Texture } & \multirow{2}{*}{ pH } & \multirow{2}{*}{$\begin{array}{c}\text { EC } \\
(\mathrm{dS} / \mathrm{m})\end{array}$} & \multirow{2}{*}{$\begin{array}{c}\text { Organic } \\
\text { matter } \\
(\%)\end{array}$} & \multirow{2}{*}{$\begin{array}{c}\mathrm{CaCO}_{3} \\
(\%)\end{array}$} & \multicolumn{4}{|c|}{ Cations (me/l) } & \multicolumn{4}{|c|}{ Anions (me/l) } \\
\hline & & & & & & & & $\mathrm{Ca}^{++}$ & $\mathbf{M g}^{++}$ & $\mathbf{K}^{+}$ & $\mathrm{Na}^{+}$ & $\mathrm{Cl}^{--}$ & $\mathrm{CO}_{3}^{-}$ & $\mathrm{HCO}_{3}^{-}$ & $\mathrm{SO}_{4}^{--}$ \\
\hline 92.52 & 2.22 & 5.26 & Sandy & 7.53 & 16.59 & 0.24 & 4.51 & 42 & 24 & 0.17 & 207 & 67.5 & 0 & 11.2 & 144.3 \\
\hline
\end{tabular}


TABLE 3. Minimum, maximum and mean daily temperature at Toshka.

\begin{tabular}{|c|c|c|c|c|c|c|c|}
\hline \multirow{2}{*}{ Month } & & \multicolumn{3}{|c|}{2015} & \multicolumn{3}{|c|}{2016} \\
\hline & & Min. & Max. & Mean & Min. & Max. & Mean \\
\hline \multirow{3}{*}{ April } & $1-15$ & 15.24 & 31.27 & 23.25 & 18.61 & 36.75 & 27.68 \\
\hline & $16-30$ & 17.03 & 35.25 & 26.14 & 19.90 & 39.41 & 29.65 \\
\hline & Mean & 16.14 & 33.26 & 24.70 & 19.25 & 38.08 & 28.67 \\
\hline \multirow{3}{*}{ May } & $1-15$ & 21.97 & 37.49 & 29.73 & 22.81 & 41.09 & 31.95 \\
\hline & $16-31$ & 23.44 & 40.07 & 31.75 & 24.20 & 40.65 & 32.43 \\
\hline & Mean & 22.70 & 38.78 & 30.74 & 23.50 & 40.87 & 32.19 \\
\hline \multirow{3}{*}{ June } & $1-15$ & 25.89 & 41.19 & 33.54 & 26.20 & 44.38 & 35.29 \\
\hline & $16-30$ & 24.47 & 39.53 & 32.00 & 25.49 & 42.55 & 34.02 \\
\hline & Mean & 25.18 & 40.36 & 32.77 & 25.85 & 43.47 & 34.66 \\
\hline \multirow{3}{*}{ July } & $1-15$ & 23.90 & 39.63 & 31.77 & 25.55 & 42.22 & 33.88 \\
\hline & $16-31$ & 24.25 & 42.76 & 33.50 & 27.38 & 41.74 & 34.56 \\
\hline & Mean & 24.08 & 41.19 & 32.63 & 26.46 & 41.98 & 34.22 \\
\hline \multirow{3}{*}{ August } & $1-15$ & 29.18 & 44.70 & 36.94 & 27.38 & 42.53 & 34.96 \\
\hline & $16-31$ & 29.11 & 43.40 & 36.25 & 25.56 & 41.34 & 33.45 \\
\hline & Mean & 29.14 & 44.05 & 36.60 & 26.47 & 41.94 & 34.20 \\
\hline \multirow{3}{*}{ September } & $1-15$ & 26.10 & 42.30 & 34.20 & 24.99 & 40.70 & 32.85 \\
\hline & $16-30$ & 27.27 & 42.27 & 34.77 & 24.28 & 39.44 & 31.86 \\
\hline & Mean & 26.68 & 42.29 & 34.49 & 24.64 & 40.07 & 32.35 \\
\hline
\end{tabular}

Characteristics measurements

After maturity, a random sample of ten plants from each unit was taken to determine pod yield/ plant, seed weight/plant, number of pods/plant, number of seeds/plant and 100 seed weight. To determine seed yield/unit, each experimental unit was harvested and weighted and converted to ton/ha.

\section{Statistical analysis}

Data were analyzed by SAS software package. Separate analysis of variance using randomized complete block design was carried out for each year and each condition level. Bartlet's test for variance homogeneity was exerted following Snedecor \& Cochran (1983), and combined analysis for data from each year and each environment level according to Gomez \& $\mid$ Gomez (1984). Means were compared by Revised Least Significant Difference (LSD) at 5\% level of significant (Steel \& Torrie, 1981).

\section{Results and Discussions}

Analysis of variance

Combined analysis of variance across years (2015 and 2016) for studied yield and yield component traits of 20 peanut genotypes under two irrigation regimes using a split plot design is presented in Table 4 . The variances due to years for pod yield/ha, pod yield/plant, seed weight/ plant, pod number/plant and seed number/plant weight were highly significant except for 100 seed was not-significant, indicating that years differ significantly for these traits and that the environmental conditions prevailed in the two seasons (weather and soil conditions) were different to the extent that affected all studied traits by years.

The variances due to irrigation treatments for the six studied yield traits, were significant ( $p \leq$ 0.01 ), indicating that water stress had a significant effect on these traits.

The main effects of genotypes were significant $(p \leq 0.01)$ for all studied traits, indicating that studied genotypes exhibited significant differences in all studied yield characters. It is observed that genotype effects were more pronounced than irrigation effects on all studied traits (Table 4).

Mean squares due to irrigation $\times$ years, genotype $\times$ years, genotype $\times$ irrigations and genotype $\times$ irrigations $\times$ years were significant $(\mathrm{p} \leq$ 0.05 or 0.01 ) for all studied traits, suggesting that rank of genotypes is different from year to year, from one irrigation regime to another and from one combination of irrigation $\times$ year to another, except irrigation $\times$ years 100 -seed weight was nonsignificant and genotype $\times$ irrigations $\times$ years were non-significant for seed number/plant and 100seed weight. 
TABLE 4. Mean squares from the combined ANOVA for pod yield/ha, pod yield/plant, seed weight/plant, no. of pod/ plant, no. of seed/pod and 100 seed weight under two water levels of 20 genotypes in 2015 and 2016 seasons.

\begin{tabular}{lccccccc}
\hline S.O.V. & DF & Pod yield ha $^{-1}$ & $\begin{array}{c}\text { Pod yield } \\
\text { plant }\end{array}$ & $\begin{array}{c}\text { Seed weight } \\
\text { plant }^{-1}\end{array}$ & Pod No. plant & $\begin{array}{c}\text { Seed No. } \\
\text { plant }^{-1}\end{array}$ & $\begin{array}{c}\text { 100 seed } \\
\text { weight }^{*}\end{array}$ \\
\hline Year (Y) & 1 & $142.47^{* *}$ & $61937.0^{* *}$ & $19169.2^{* *}$ & $15280.1^{* *}$ & $56478.8^{* *}$ & 7.91 \\
Irri. (I) & 1 & $276.69^{* *}$ & $89919.5^{* *}$ & $32352.4^{* *}$ & $26818.2^{* *}$ & $25172.0^{* *}$ & $11626.68^{* *}$ \\
Y×I & 1 & $5.659^{* *}$ & $2538.3^{* *}$ & $1048.8^{* *}$ & $717.6^{* *}$ & $509.5^{*}$ & 0.17 \\
Error (a) & 8 & 0.25 & 84.5 & 9.7 & 66.0 & 72.4 & 16.95 \\
Genotype (G) & 19 & $25.66^{* *}$ & $8417.5^{* *}$ & $2125.8^{* *}$ & $2760.2^{* *}$ & $5247.3^{* *}$ & $552.44^{* *}$ \\
Y $\times \mathrm{G}$ & 19 & $3.02^{* *}$ & $1121.9^{* *}$ & $346.1^{* *}$ & $378.7^{* *}$ & $834.7^{* *}$ & $15.86^{* *}$ \\
$\mathrm{I} \times \mathrm{G}$ & 19 & $1.97^{* *}$ & $647.4^{* *}$ & $262.1^{* *}$ & $248.7^{* *}$ & $164.4^{* *}$ & $70.80^{* *}$ \\
$\mathrm{Y} \times \mathrm{I} \times \mathrm{G}$ & 19 & $0.35^{* *}$ & $122.5^{* *}$ & $48.7^{* *}$ & $46.7^{* *}$ & 39.2 & 3.88 \\
Error (b) & 152 & 0.07 & 24.2 & 8.7 & 11.8 & 24.9 & 5.06 \\
\hline
\end{tabular}

* and **: significant at 0.05 and 0.01 levels of probability, respectively.

Significance ofmain effects of peanutgenotypes, irrigation treatments and their interactions of the present study confirms the findings of pervious investigators; i.e. Clavel et al. (2006) and Jongrungklang et al. (2012) for genotypes, Arunyanark et al., (2009), Dinh et al. (2013) and Arruda et al. (2015) for irrigation regimes and Girdthai et al. (2010) and Arunachalam \& Kannan (2013) for genotype $\times$ irrigation interaction.

Moreover, significant interaction between genotypes and irrigation treatments indicated that selection is possible to be practiced under a specific irrigation treatment (Jongrungklang et al., 2008; Girdthai et al., 2010; Arunachalam \& Kannan, 2013 and Pereiral et al., 2015).

\section{Effect of peanut genotype}

In general, lines varied significantly in all studied traits (Table 5). High values of all studied traits were considered favorable. The line L17 showed the highest (most favorable) means for pod yield/ha, pod yield/plant, seed weight/plant, pod number/plant, 100-seed weight and seed number/ plant weight and superiority. The lines L11, L13, L14 and L19 ranked second, third, fourth and fifth, respectively for the same traits except for 100-seed weight. For 100-seed weight, the lines L3, L18 and L16, respectively came in the first rank and showed the highest means for this trait. These lines showed significant increase more than the check line L20 (NC).

On the contrary, the linesL1 and L5 showed the lowest means for pod yield/ha (ton), pod yield/ plant (g). For seed weight/plant and 100 seed weight, the line L4 showed the lowest mean for these traits. For no. of pod/plant and no. of seed/ plant the line L3 came in the last rank and achieved the lowest means among all lines for these trait in this study.

This result indicated that it is possible to obtain a high yielding and high yield component simultaneously, in spite of the positive correlation mentioned in the review between grain yield and yield component, confirming the results of Pimratch et al. (2008a). High pod yield was recorded in some peanut genotypes (Puangbut et al., 2009 and 2011)

Genotypic variation in peanut yield traits was reported by several investigators (Rucker et al., 1995; Pimratch et al., 2008a; Pimratch et al., 2010 and Pereiral et al., 2015). The existence of genetic variability for yield traits indicates that these traits of peanut could be improved by conventional breeding programs.

Peanut lines $\times$ irrigation regime interaction:

Means of each peanut line and check line for studied seed yield and yield traits under contrasting irrigation regimes, i.e. well watering and water stress across two years are presented in Table 6 . The highest mean for pod yield per hectare, pod yield per plant, seed weight per plant and pod per plant was recorded for the peanut line L11 followed by L17 and L19 and for 100 seed weight for peanut line L18 and L3 and for no. of seed per plant for the peanut line L19, L14 and L11 under both irrigation 
regimes, while the lowest ones for pod yield per hectare and pod yield per plant were exhibited by L1, for seed weight per plant and 100 seed weight for line L4, for no. of pod per plant and no of seed per plant for line L3.

TABLE 5. Means of studied grain component and yield traits of 20 genotypes peanut across two irrigation regimes combined across 2015 and 2016 seasons.

\begin{tabular}{|c|c|c|c|c|c|c|}
\hline Genotype & $\begin{array}{l}\text { Pod yield } \\
\text { ha-1 (ton) }^{-1}\end{array}$ & $\begin{array}{l}\text { Pod yield/ } \\
\text { plant (g) }\end{array}$ & $\begin{array}{c}\text { Seed weight/ } \\
\text { plant (g) }\end{array}$ & $\begin{array}{l}\text { No. of pod/ } \\
\text { plant }\end{array}$ & 100 seed weight & $\begin{array}{c}\text { No. of seeds/ } \\
\text { plant }\end{array}$ \\
\hline $\mathrm{L} 1$ & 2.92 & 52.54 & 33.28 & 42.58 & 53.09 & 62.03 \\
\hline L2 & 4.22 & 76.17 & 42.34 & 48.17 & 54.87 & 76.97 \\
\hline L3 & 3.35 & 60.42 & 33.84 & 32.08 & 70.5 & 47.6 \\
\hline L4 & 3.27 & 58.75 & 25.89 & 41.08 & 44.58 & 57.83 \\
\hline L5 & 3.13 & 56.29 & 34.03 & 48 & 46.07 & 72.9 \\
\hline L6 & 3.85 & 69.38 & 39.25 & 43.75 & 56.32 & 68.48 \\
\hline L7 & 4.37 & 78.75 & 41.95 & 46.58 & 59.78 & 69.39 \\
\hline L8 & 3.76 & 67.79 & 37.33 & 50.08 & 49.31 & 75.48 \\
\hline L9 & 3.35 & 60.33 & 31.58 & 37.08 & 61.52 & 50.72 \\
\hline L10 & 5.07 & 91.38 & 43.23 & 56.42 & 50.9 & 84 \\
\hline L11 & 7.59 & 137.04 & 71.24 & 81.5 & 54.55 & 127.93 \\
\hline L12 & 5.52 & 99.63 & 51.92 & 55.75 & 61.93 & 82.16 \\
\hline L13 & 6.52 & 117.67 & 60.18 & 66.08 & 59.65 & 98.61 \\
\hline L14 & 6.5 & 117.33 & 61.09 & 77.75 & 55.46 & 108.49 \\
\hline L15 & 4.52 & 81.42 & 45.98 & 51.92 & 57.22 & 79.93 \\
\hline L16 & 4.88 & 88 & 49.76 & 54.42 & 65.44 & 74.89 \\
\hline L17 & 7.64 & 137.96 & 68.35 & 85.25 & 63.92 & 104.23 \\
\hline L18 & 5.02 & 90.54 & 48.7 & 51.67 & 67.29 & 71.21 \\
\hline L19 & 6.49 & 117.17 & 68.61 & 77.67 & 60.64 & 111.58 \\
\hline L20(Check) & 4.57 & 82.33 & 42.13 & 46.92 & 58.73 & 70.08 \\
\hline Average & 4.83 & 87.04 & 46.53 & 54.74 & 57.59 & 79.72 \\
\hline LSD0.05 & 0.18 & 3.29 & 1.97 & 2.3 & 3.34 & 1.51 \\
\hline LSD0.01 & 0.26 & 4.68 & 2.81 & 3.27 & 4.75 & 2.14 \\
\hline
\end{tabular}




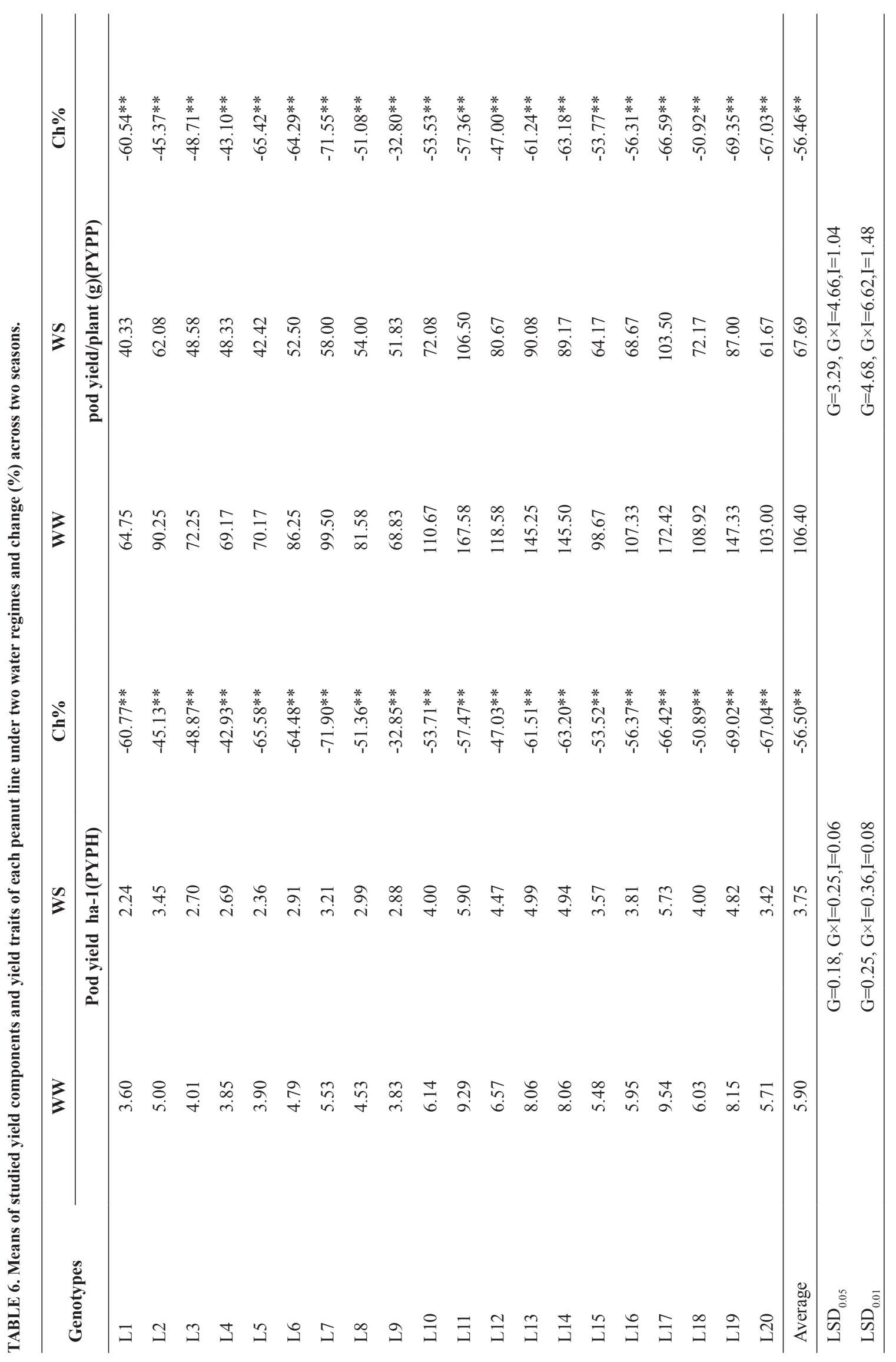

Egypt. J. Agro. Vol. 40, No. 1 (2018) 


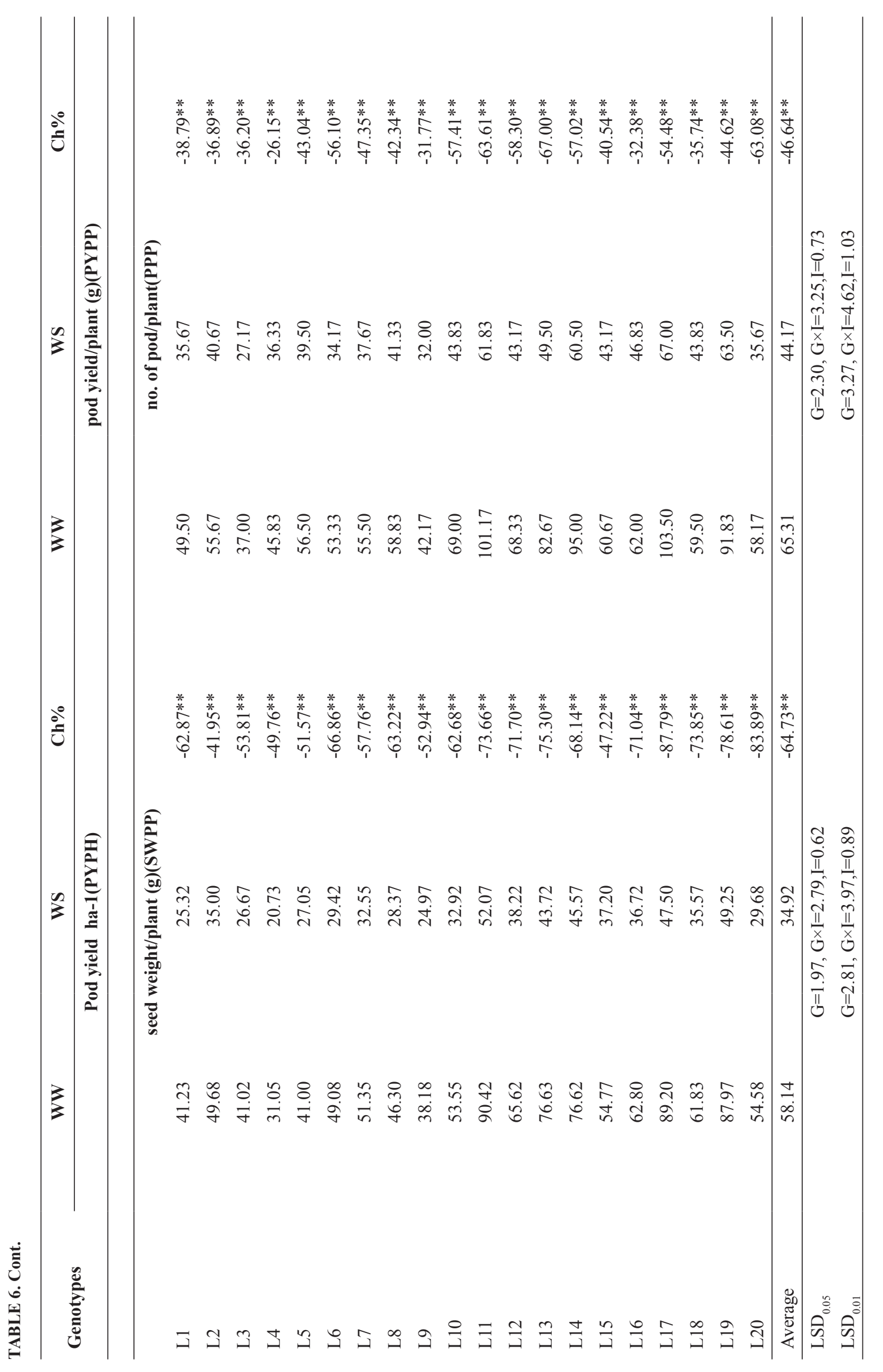

Egypt. J. Agro. Vol. 40, No. 1 (2018) 


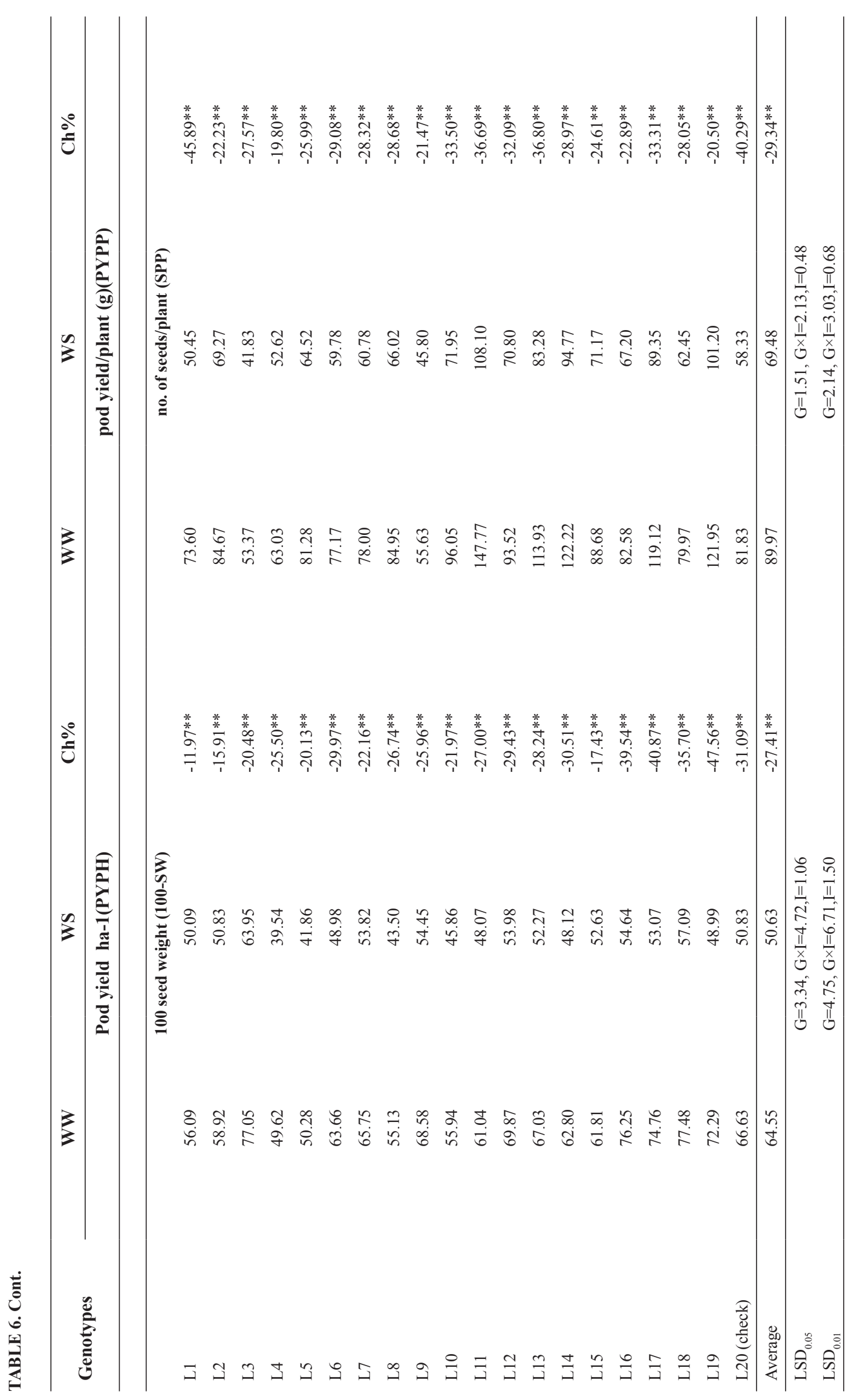

Egypt. J. Agro. Vol. 40, No. 1 (2018) 
The superiority of the line 17 in pod yield/ha over the check under water stress was associated with superiority in pod yield/plant, seed weight/plant, no. of pod/ plant no. of seed/plant $(40.42,37.52,46.76$ and 34.72 , respectively).

\section{Grouping genotypes}

Based on relationships between means under water stress and well watering

Mean of pod yield per hectare across years of studied genotypes under well watering (WW) or water stress (WS) was plotted against same trait of the same genotypes under well watering (WW) or water stress (WS) and illustrated in Fig. 1, where numbers from 1 to 20 refer to peanut lines names from L1 to L20, respectively. This made it possible to distinguish between efficient and inefficient peanut lines on the basis of above-average and below-average studied trait under WW or WS together and responsive and non-responsive peanut lines on the bases of above-average and below-average same trait under WW or WS together (Stansell \& Pallas, 1985; Vorasoot et al., 2003; Upadhyaya, 2005; Pimratch et al., 2008b; Songsri et al., 2008a; Songsri et al., 2008b and Wunna et al., 2009). Similarly, means of other studied yield traits (PYPP, SWPP, PPP, 100-SW and SPP) under WS were plotted against means of the same traits for the same peanut lines under WW conditions. According to Fig. 1 , studied lines was classified into four groups, i.e. water efficient and responsive, water efficient and nonresponsive, water inefficient and responsive and water inefficient and non-responsive based on pod yield/ha, pod yield/plant, seed weight/ plant, number of pod/plant, 100 seed weight and number of seed/plant. Based on this classification, the line No. 11(L11), No.13 (L13), No.17 (L17) and No. 19 (L19) had the highest per se means of pod yield/ ha, pod yield/plant, seed weight/plant, number of pod/plant, and number of seed/ plant under WW and WS simultaneously, i.e. they could be considered as the most water use efficient and the most responsive peanut lines in this study (Fig. 1). On the contrary, the peanut lines No.1 (L1), No.5 (L5), No.3 (L3), No.4 (L4), No.9 (L9), No.8 (L8), No.6 (L6), No.7 (L7) and No.20 (L20) had the lowest means of pod yield/ha, pod yield/plant, seed weight/plant, number of pod/plant, 100 seed weight and number of seed/plant under both WW and WS and could therefore be considered inefficient and nonresponsive lines (Fig. 1).

Based on drought tolerance and pod yield and other traits under water stress

According to drought tolerance index and mean of each pod yield/ha, pod yield yield/plant, seed weight/plant, number of pod/plant, 100 seed weight and number of seed/plant under water stress, studied genotypes were classified into four groups, i.e. tolerant and high-yielding, tolerant and low-yielding, sensitive and high-yielding and sensitive and low-yielding (Fig. 2).

Based on this classification, the lines L1 1 and L17 exhibited tolerance and high yield, pod yield/ha, number of pod/plant, pod yield per plant, seed per plant and seed weight per plant under water stress conditions. By contrary, the peanut lines L1 and occupied the sensitive and low-yielding group (Fig. 2).

\section{Conclusions}

This investigation concluded that water stress causes a significant reduction in peanut lines pod yield/ha, pod yield/plant, seed weight/plant, number of pod/plant, 100 seed weight and number of seed/plant. The rank of peanut lines for studied traits under WS was changed from that under well watering conditions. Developing drought tolerant (T) lines of peanut gave them superiority over sensitive (S) ones in all studied yield parameters (pod yield/ ha, pod yield/plant, seed weight/plant, number of pod/plant, 100 seed weight and number of seed/plant) under water stress conditions. It was possible to identify the best water-efficient and responsive lines (L11, L17, L19, L13 and L14), the best tolerant and high-yielding, seed weight and number of pod/plant genotypes (L17 and L11). They could be offered to future breeding programs for improving water stress tolerance, yielding ability and seed yield component traits of peanut genotypes. 

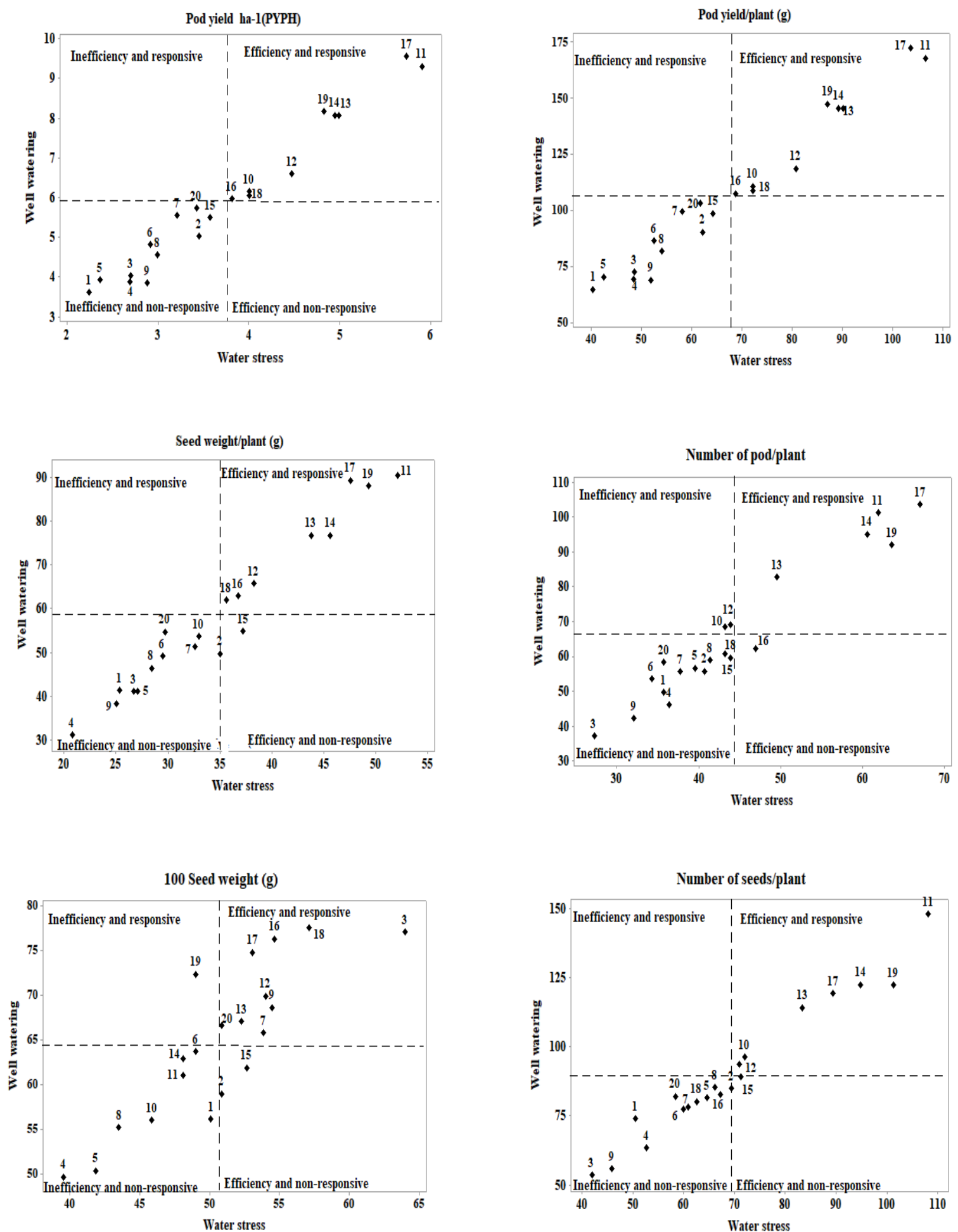

Fig. 1. Relationships between efficiency and responsiveness for pod yield/ha (PYPH), pod yield/plant (PYPP), seed weight/plant (SWPP), number of pod/plant (PPP), 100 seed weight $(100-S W)$ and number of seed/plant (SPP) of 20 peanut lines under water stress and well watering, combined across two seasons. Numbers from 1 to 20 refer to lines names. 

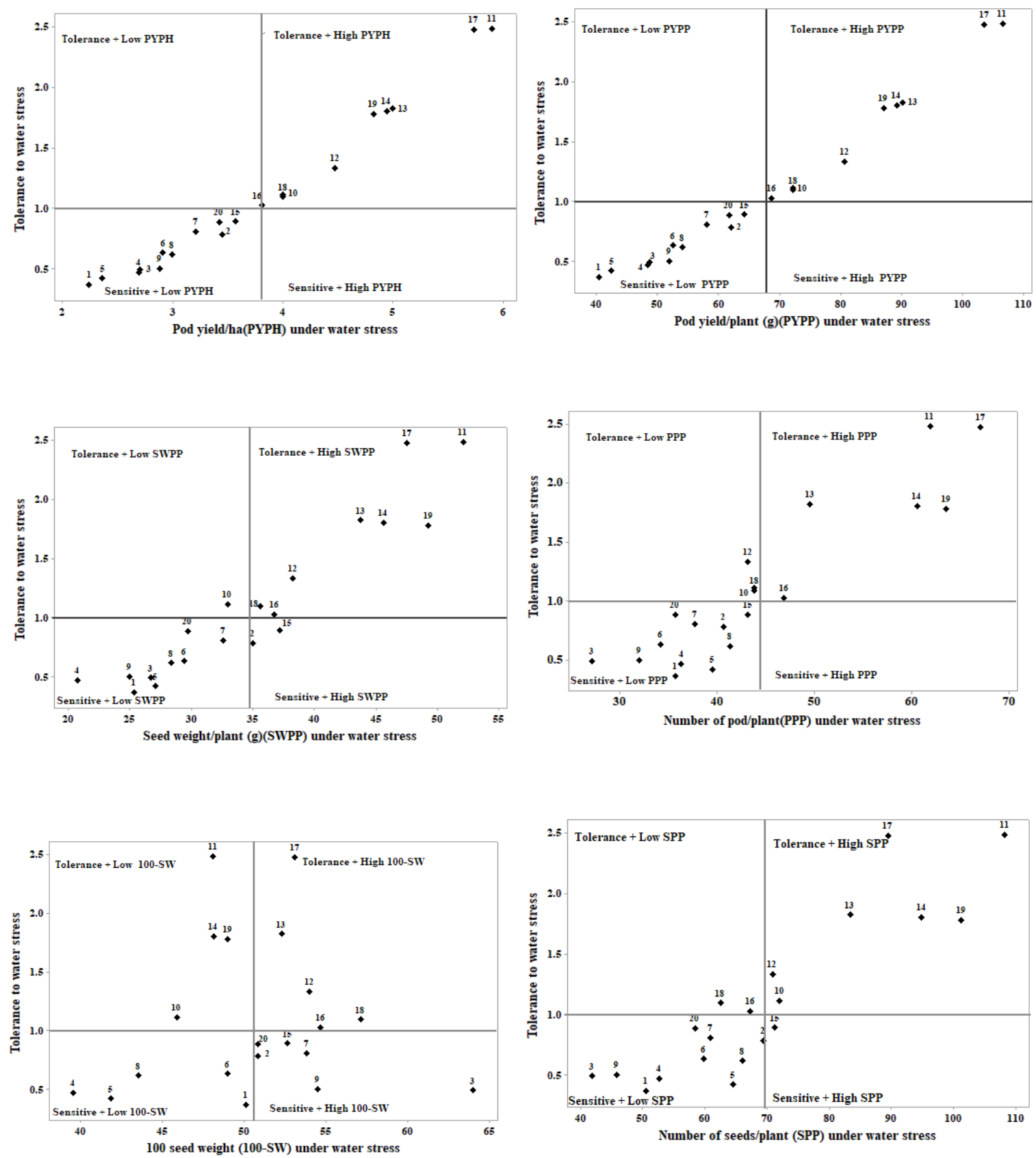

Fig. 2. Relationships between tolerance index (TI) and means of pod yield/ha (PYPH), pod yield/plant (PYPP), seed weight/plant (SWPP), number of pod/plant (PPP), 100 seed weight (100-SW) and number of seed/plant (SPP) of 20 peanut lines under water stress and well watering, combined across two seasons. Numbers from 1 to 20 refer to lines names. 


\section{References}

Arruda, I.M., Moda-Cirino, V., Buratto, J.S. and Ferreira, J.M. (2015) Growth and yield of peanut cultivars and breeding lines under water deficit. ISSN 19834063 - www.agro.ufg.br/pat - Pesq. Agropec. Trop., Goiânia, 45(2), 146-154.

Arunachalam, P. and Kannan, P. (2013) Screening for drought tolerant groundnut (Arachis hypogaea L.) lines suitable for rainfed. Asian J. Agri. Res. 7(1), $35-42$.

Arunyanark, A., Jogloy, S., Wongkaew, S., Akkasaeng, C., Vorasoot, N., Wright, G.C., Rachaputi, R.C.N. and Patanothai, A. (2009) Association between aflatoxin contamination and drought tolerance traits in peanut. Field Crop Res. 114, 14-22.

Ashraf, M. (2010) Inducing drought tolerance in plants. Biotechnological Advances, 28, 169-183.

CGIAR (2005) Groundnut (Arachis hypogaea L.). Consultative Group on International Agricultural Research. http://www.cgiar.org/ impact/researchground nut.html.

Chaves, M.M., Flexas, J. and Pinheiro, C. (2009) Photosynthesis under drought and salt stress: Regulation mechanisms from whole plant to cell. Annals of Botany, 103, 551-560.

Clavel, D., Diouf, O., Khalfaoui, J.L. and Braconnier, S. (2006) Genotypes variations in fluorescence parameters among closely related groundnut (Arachis hypogaea L.) lines and their potential for drought screening programs. Crop Sci. 34, 92-97.

Dinh, H.T., Kaewpradit, W., Jogloy, S., Vorasoot, N. and Patanothai, A. (2013) Biological nitrogen fixation of peanut genotypes with different levels of drought tolerance under mid-season drought. SABRAO J. Breed. Genet. 45(3), 491-503.

Girdthai, T., Jogloy, S., Vorasoot, N., Akkasaeng, C., Wongkaew, S., Holbrook, C.C. and Patanothai, A. (2010) Associations between physiological traits for drought tolerance and aflatoxin contamination in peanut genotypes under terminal drought. Plant Breed. 129, 693-699.

Gomez, K.A. and Gomez, A.A. (1984) "Statistical Procedures for Agriculture Research". John Wiley and Sons. Inc. New York, USA.

ICRISAT (2011) Groundnut (Arachis hypogaea L.). International Crops Research Institute for the SemiArid Tropics. http://www.icrisat.org/crop-groundnut. htm.
Jongrungklang, N., Toomsan, B., Vorasoot, N., Jogloy, S., Boote, K.J., Hoogenboom, G. and Patanothai, A. (2012) Classification of root distribution patterns and their contributions to yield in peanut genotypes under mid-season drought stress. Field Crops Res. 127, 181-190.

Jongrungklang, N., Toomsan, B., Vorasoot, N., Jogloy, S., Kesmala, T. and Patanothai, A. (2008) Identification of peanut genotypes with high water use efficiency under drought stress conditions from peanut germplasm of diverse origins. Asian J. Plant Sci. 7, 628-638.

Kumar, V. (2007) Agrometeorology and groundnut production. $\mathrm{WMO} / \mathrm{CAgM}$ guide to agricultural meteorological practices (GAMP). Interaction of water stress and mineral nutrition on growth and yield. In: "Adaptation of Plants to Water and High Temperature Stress".Turner, N.C., Kramer, P.J. (Ed.), John Wiley \& Sons, New York.

Murakami, D.M., Cardoso, A.A., Cruz, C.D. and Bizão, N. (2004) Considerações sobre duas metodologias de análise de estabilidade e adaptabilidade. Ciência Rural, 34, 71-78.

Pereiral, J.W., A.da Silva, E.C., Luz, L.N., Nogueira, R.J.M.C., Filho, P.A.M., Lima, L.M. and Santos, R.C. (2015) Cluster analysis to select peanut drought tolerance lines. Asian J. Crop Sci. (AJCS), 9(11), 1095-1105.

Pimratch, S., Jogloy, S., Vorasoot, N., Toomsan, B., Patanothai, A. and Holbrook, C.C. (2008a) Relationship between biomass production and nitrogen fixation under drought stress conditions in peanut genotypes with different levels of drought resistance. J. Agron. Crop Sci. 194, 15-25.

Pimratch, S., Jogloy, S., Vorasoot, N., Toomsan, B., Kesmala, T., Patanothai, A. and Holbrook, C.C. (2008b) Effect of drought stress on traits related to $\mathrm{N}_{2}$ fixation in eleven peanut (Arachis hypogaea L.) genotypes differing in degrees of resistance to drought. Asian J. Plant Sci. 7, 334-342.

Pimratch, S., Jogloy, S., Vorasoot, N., Toomsan, B., Kesmala, T., Patanothai, A. and Holbrook, C.C. (2010) Effects of drought on characters related to nitrogen fixation in peanut. Asian J. Plant Sci. 9, 402-413.

Puangbut, D., Jogloy, S., Vorasoot, N., Akkasaeng, C., Kesmala, T. and Patanothai, A. (2009) Variability in yield responses of peanut (Arachis hypogaea L.) genotypes under early season drought. Asian $J$. Plant Sci. 8, 254-264. 
Puangbut, D., Jogloy, S., Vorasoot, N., Akkasaeng, C. and Patanothai, A. (2011) Association of transpiration efficiency with $\mathrm{N}_{2}$ fixation of peanut under early season drought. Int. J. Plant Prod. 5, 381-394.

Rucker, K.S., Kvien, C.K., Holbrook, C.C. and Hook, J.E. (1995) Identification of peanut genotypes with improved drought avoidance traits. Peanut Sci. 22, 14-18.

Snedecor, G.W and Cochran, W.G. (1983) "Statistical Methods" (6 $6^{\text {th }}$ ed.) Oxford and IBH, New Delhi.

Songsri, P., Jogloy, S., Vorasoot, N., Akkasaeng, C., Patanothai, A. and Holbrook, C.C. (2008a) Root distribution of drought-resistant peanut genotypes in response to drought. J. Agron. Crop Sci. 194, 92-103.

Songsri, P., Jogloy, S., Kesmala, T., Vorasoot, N., Akkasaeng, C., Patanothai, A. and Holbrook, C.C. (2008b) Response of reproductive characters of drought resistant peanut genotypes to drought. Asian J. Plant Sci. 7, 427-439.
Stansell, J.R. and Pallas Jr., J.E. (1985) Yield and quality response of Florunner peanut to applied drought at several growth stages. Peanut Sci. 12, 64-70.

Steel, G.D. and Torrie, J.H. (1981) "Principles and Procedures of Statistics" ( $2^{\text {nd }}$ ed.). McGraw Hill Book Company. Inc. N. Y. xxi-633pp.

Upadhyaya, H.D. (2005) Variability for drought resistance related traits in the mini core collection of peanut. Crop Sci. 45, 1432-1440.

Vorasoot, N., Songsri, P., Akkasaeng, C., Jogloy, S. and Patanothai, A. (2003) Effect of water stress on yield and agronomic characters of peanut (Arachis hypogaea L.). Songklanakarin J. Sci. Technol. 25(3), 283-288.

Wunna, H., Jogloy, S., Toomsan, B. and Sanitchon, J. (2009) Response to early drought for traits related to nitrogen fixation and their correlation to yield and drought tolerance traits in peanut (Arachis hypogaea L.). Asian J. Plant Sci. 8, 138-145.

Zhu, J.K. (2002) Salt and drought stress signal transduction in plants. Annual Reviews of Plant Biology, 53, 247-273.

(Received 10/12/2017; accepted 15/3/2018) 


\section{تاثير الجفاف على المحصول ومكوناته لـ 20 تركيب وراثى من الفول السودانى المنزرعة تحت ظروف الأراضى الرملية المستصلحة حديثا

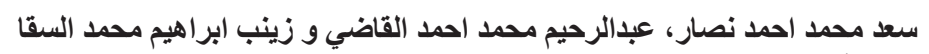

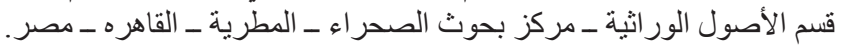

أجريت هذه الدراسة بمحطة بحوث توشكي - مركز بحوث الصحر اء، خلال موسمين زر اعيين (2015 و و

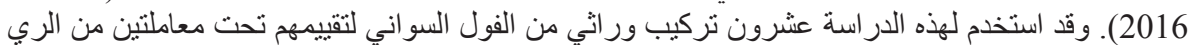

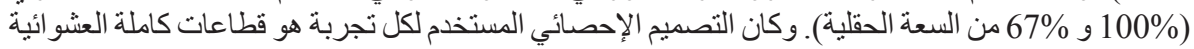
مع استخدام ثلاث مكررات.

أظهر التحليل الإحصائي فروقا معنوية بين التر اكيب الور اثية لكل الصفات التي تم دراستها تحت معاملتي الري وكذلك التحليل المشترك لهم.

أدت معاملة الجفاف إلى نقص ملحوظ في كل الصفات تحت الدر اسة مقارنة بظروف الري العادي.

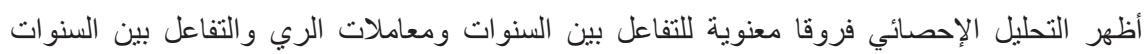

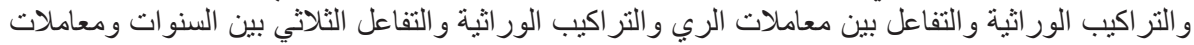

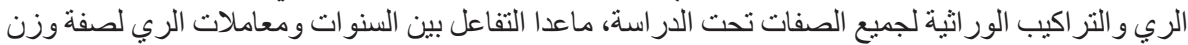

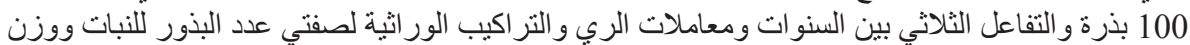
100

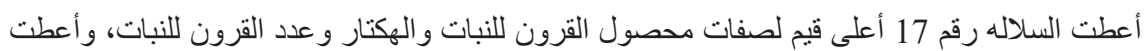

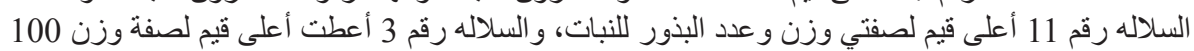

